\title{
The State of Education in Alabama's K-12 Rural Public Schools
}

\author{
Ronald A. Lindahl \\ Alabama State University
}

The purpose of this study was to compare Alabama's rural school districts with its city, suburban, and town districts. Descriptive statistics were used for this population study, with effect sizes calculated using Cohen's d. Findings indicated Alabama's rural school districts serve slightly less affluent student populations, with a lower percentage of minority students, than their counterparts. They are funded at slightly lower levels than their counterparts in other categories, yet spend approximately the same percentage of their budgets on administration and on instruction. They spend a considerably higher percentage on transportation. Although rural district dropout rates are similar to those of their counterparts, from the third to the eleventh grade, student performance on standardized examinations falls gradually behind that of the students in other locale categories.

Keywords: Alabama schools; rural schools; student performance; school funding

Alabama is among the 13 states where rural education is most important to the overall educational performance of the state (Johnson \& Strange, 2007, p. i), yet it is among the four states least conducive to rural educational achievement (p. ii). Clearly, rural education is one aspect of the public educational system that merits serious attention, particularly in Alabama. Unfortunately, as Arnold (2004) noted, "[r] elatively little high quality research has been conducted about rural education issues over the past two decades" (n.p.). This study attempts to add to that knowledge base by investigating the levels of student achievement in Alabama's rural schools, as compared to their town, suburban, and city counterparts. It also compares the socio-economic levels of students, racial/ethnic diversity, per-pupil expenditures, revenue sources, and expenditures for instruction, administration, and transportation.

\section{Research Questions}

Arnold (2004) identified some high priority areas for rural schools research. Two of those areas - student achievement and school finance - were selected as the focus of this investigation into Alabama's rural public schools. Against that backdrop, the research questions that guided this study were:

1. What are the levels of student academic achievement in Alabama's rural schools, as measured by:

(a) scores on selected standardized examinations

(b) projected four-year dropout rates

(c) percentages of students in career and technical programs

2. How do rural student achievement levels compare to those of students in Alabama's town, suburban, and city public school districts?
3. To what extent does the socio-economic level of the students the districts serve vary by the locale of the district?

4. To what extent do per-pupil expenditures vary in relation to the locale of the school district?

5. To what extent do the percentages of funds districts spend on instruction, administration, and transportation vary by the locale of the school district?

6 . To what extent do revenue sources vary by the locale of the district?

\section{Research on Rural Schools}

The purpose of this brief review of the research on rural schools is to present the major national findings related to the variables examined, which include student achievement, transportation issues, socio-economic characteristics of rural schools, financial issues affecting rural schools, and district and school size considerations.

\section{Student Performance in Rural Schools}

It is crucial to recognize that rural schools differ greatly from each other (Rural Education, 2004). Lee and McIntire (2000) concluded that rural students perform significantly better than non-rural students in some states, but significantly poorer in others. Analysis of the 2003 NAEP data revealed both fourth and eighth grade students in rural schools perform at similar levels in reading and math to students in suburban schools, but slightly better than city students (National Center for Education Statistics [NCES], 2003). The Rural School and Community Trust (2009) released the following national data on reading performance (percentile of students scoring at the Proficient level or higher) by school locale: Rural $-43^{\text {rd }}$ percentile; town $-43^{\text {rd }}$ 
percentile; suburban $-57^{\text {th }}$ percentile; city $-38^{\text {th }}$ percentile.

Examining 2004 data, Provasnik et al. (2007) found little difference in the percentages of special needs students across the four local classifications. However, they found the high school status dropout rate among 16 to 24 -year-olds to be $11 \%$ in rural areas, compared to $9 \%$ in suburban areas and $13 \%$ in city schools (p. iv).

\section{Transportation Issues in Rural Schools}

Rural schools often must transport their students over long distances. Hours spent travelling before and after school can have negative effects on student performance (Reeves, 2003, p. 5), such as sleep deprivation (Wolfson \& Carskadon, 2003). Even a loss of only 15 to 30 minutes can make the difference between students earning A or B grades or earning Cs. Travel distances can also negatively impact parent involvement in schools (Reeves, 2003, p. 6). However, research findings on rural parental involvement are conflicting. Howley and Maynard (2009) found rural school parents no less involved than suburban or city school parents. They noted that schools in rural communities are often at the center of community life as rural families are often isolated from such educational resources as museums, libraries, colleges, and universities. Low incomes in many rural areas may limit the amount of educational resources in the homes, and, compounded with a lack of local job opportunities related to educational achievement, rural students can be at a distinct disadvantage.

\section{Socio-economic Issues in Rural Schools}

Fifty-seven percent of the school districts in the U.S. are rural, serving $22 \%$ of all public school students in the nation (National Center for Education Statistics, 2009). Of the students served by rural schools, $22.9 \%$ are minority students and $14.7 \%$ are special needs students (Johnson \& Strange, 2007, p. 4). There is a higher percentage of White students in rural schools than in other locales, but lower percentages of Black, Hispanic, and Asian students (Provasnik et al., 2007, p. iii). The percentage of rural students qualifying for free or reduced price lunch $(38 \%)$ is lower than that for cities $(58 \%)$ and towns (43\%) (Provasnik et al., p. iv). Only $83.7 \%$ of rural adults have high school diplomas or the equivalent, and the median rural household income was only $\$ 46,145$ (Provasnik et al., p. 4).

Johnson and Strange (2009) found that the 900 rural school districts with the highest student poverty rates lie largely in the South and serve approximately 1.4 million students, $37 \%$ of whom are socio-economically disadvantaged and $59 \%$ of whom are people of color. They concluded that students in states with more rural poverty and greater socio-economic diversity perform lower on standardized examinations and have higher dropout rates. In a study that investigated graduation rates in 800 rural districts with the highest poverty rates in the South and Southwest, Johnson, Strange, and Madden (2010) concluded that just over $60 \%$ of these rural students can be expected to graduate compared with $67 \%$ in non-rural districts.

Poverty in city schools tends to be multi-cultural, whereas in rural schools, the poor tend to be from one ethnic group (Lomotey \& Swanson, 1989, p. 438). Nationally, a higher percentage of Black and American Indian/Alaska Native students in rural areas attended moderate-to-high poverty public schools than in cities (National Center for Education Statistics, 2007). The completion rates for minority students in rural schools are lower than for Whites, and lower than for minority students in city schools (Lomotey \& Swanson, 1989, p. 440). More recent data from the Urban Policy Institute (Swanson, 2003) indicate that the completion rate for minority students is lower than that of Whites and that the graduation rate of students in rural schools is less than one percent below that of those in suburban schools (71.9\% v 72.7\%), but ahead of town schools (69.1\%) and city $(57.5 \%)$. Unfortunately, no more recent studies were found that examined the performance of minority youth in rural schools. Even the National Center for Educational Statistics' 2007 Common Core of Data did not present tables related to this issue.

In Alabama, minority students in rural schools are predominantly African-American. In their national study, Farmer, Leung, Banks, Schaefer, Andrews, and Murray (2006) found that in over $40 \%$ of the rural schools serving poor, minority youth, a disproportionate percentage of African-American students did not pass the end-of-year exams and were in danger of dropping out. These schools are concentrated in the Southwest and South, and include Alabama's schools (p. 5).

Nationwide, approximately six million students change schools each school year (Paik \& Phillips, 2002, p. 6). This student mobility occurs as frequently in rural schools as in city schools. Such mobility is strongly, and negatively, related to family income levels. Frequent movers are more likely to exhibit behavior problems, lower academic performance, and lower graduation rates (pp. 6-7).

Teachers in rural public schools are more experienced but less racially diverse than their counterparts in non-rural schools. They earn less than teachers in towns, suburbs, or city areas, but are more satisfied with their working conditions than all but teachers in suburban schools (National Center for Education Statistics, 2009). 


\section{Funding Issues in Rural Schools}

Lomotey and Swanson (1989) noted that rural schools are often not funded as well as city and suburban schools (p. 447). Over 20 years later, this disparity continues. Johnson et al. (2010) found that the 800 rural Southern and Southwestern districts serving highpoverty students operate with less state and local funding per pupil $(\$ 7,731)$ than all other rural districts $(\$ 8,134)$ or all non-rural districts $(\$ 9,611)$. These figures did not include federal funding, however. Alabama's rural instructional expenditures per pupil $(\$ 4,373)$ compare poorly to the national average $(\$ 5,554)$ (Johnson \& Strange, 2009).

The positive relationship between funding and student performance is generally accepted (Odden \& Picus, 2004); however, it is a difficult relationship to confirm. Hanushek (1997) stated that sometimes resources are used effectively; sometimes they are not. Consequently, higher per-pupil expenditures may not be positively related to better education. Another explanation is that over the past three decades, the majority of new funding provided to schools has not been spent on the core instructional program, but rather on programs and services for special populations. These programs, unfortunately, show few long-lasting effects on student achievement (Allington \& Johnston, 1989; Odden, 1991; Odden \& Picus, 2004; Reynolds \& Wolfe, 1999).

Another funding issue generally considered to be linked to student performance is the percentage of the overall budget that is spent on instruction. However, in a three-state survey (Florida, New York, and California), Odden and Picus (2004, p. 284) found that the instructional budget varies relatively little among districts, with a range of only $58.4 \%$ to $61.8 \%$.

A final funding issue associated with rural schools is the board's ability and willingness to raise local funds to supplement state funding. "In districts with extremely limited fiscal capacity, adequate educational opportunities cannot be provided unless the taxpayers make an excessive fiscal effort" (Alexander \& Salmon, 1995, p. 151).

\section{School and District Size Issues in Rural Schools}

Considerable research has been conducted on both district size (e.g., Driscoll, 2008; Niskanen, 1988) and school size (e.g., Leithwood \& Jantzi, 2009). Although rural districts and their schools tend to be smaller than city districts, research on school and district size generally did not differentiate results by school locale.

Rural school districts are generally small. In examining district size, Bickel and Howley (2000), Howley (2003), and Howley, Strange, and Bickel (2000) found that students in small districts performed better than students in larger districts. Huang and Howley (1993) and Howley (1996) found smaller districts particularly beneficial for students from low socioeconomic backgrounds.

Alexander and Salmon (1995) concluded that "small school districts usually offer less adequate educational programs, are less efficient, and are more expensive to operate than larger schools and districts" (p. 149). Rural public schools have lower pupil-to-teacher ratios than schools in other locales and have lower pupil-to-staff ratios for counselors, social workers, school psychologists, and special education instructional aides. Students in rural schools have slightly greater access to computers with Internet connectivity than do students in other locales (National Center for Education Statistics, 2009).

Two decades ago, one-fifth of the schools in small rural districts had less than one teacher per grade. In 1993-1994, high schools in $80 \%$ of rural districts had less than 100 students per grade level (National Center for Education Statistics, 1997). Rural schools continue to be small today. In 2003-2004, a larger percentage (10\%) of rural students attended very small schools (less than 200 students) than in towns $(3 \%)$, suburbs $(1 \%)$, or cities (1\%) (National Center for Education Statistics, 2007, p. iii).

In their meta-analysis of 18 studies on the relationship of high school size to student performance, Leithwood and Jantzi (2009) noted that five studies found a positive relationship, whereas eight studies found a negative relationship. Six studies identified the relationship as an "inverted U," where achievement related positively to school size until an optimal size was reached, at which point the relationship became negative. Effect sizes in all studies ranged from very small to moderate. Lee and Smith (1997) also identified this non-linear relationship. They found that students in high schools with between 600 and 900 students scored best in reading and math, with students in both smaller and larger high schools faring less well. A different curvilinear relationship was identified by Werblow and Duesbery (2009), who found that math gains were highest in very large and very small high schools. However, in a study of Iowa's small, rural high schools, Johnson (2006) found that high schools of less than 200 students produced the highest math and reading scores. Thus results are conflicting, which is unsurprising as many variables impact student achievement.

\section{Definition of Rural Schools}

Although many definitions of rural schools abound in the knowledge base, the most generally-accepted definition of school locale is the one provided by the National Center for Educational Statistics (NCES, 2009) for its Common Core of Data; that definition and the 
codes assigned to each district in that database formed the basis for classifying schools in this study. The NCES revised its local classification system following the 2000 Decennial Census. The new classifications are based on the school's and district's proximity to an urbanized area. Four basic types were identified (each sub-divided further into three subsets): rural, town, suburban, and city. Slightly more than $31 \%$ of the public schools in the U.S. are classified as rural (NCES, 2009).

Rural districts are further classified into fringe rural districts, distant rural districts, and remote rural districts. Fringe rural districts are defined by the National Center for Educational Statistics (2009) as rural territories that are less than or equal to 5 miles from an urbanized area, as well as rural territories that are less than or equal to 2.5 miles from an urban cluster. Distant rural districts are defined as rural territories that are more than 5 miles but less than or equal to 25 miles from an urbanized area, as well as rural territories that that are more than 2.5 miles but less than or equal to 10 miles from an urban cluster. Remote rural districts are more than 25 miles from an urbanized area and more than 10 miles from an urban cluster. However, due to the limited number of school districts in Alabama $(\mathrm{N}=130)$, data in this study were examined only at the city, suburban, town, and rural levels of the classification schema.

\section{Methodology}

The design for this study was descriptive. The population chosen for this study included all regular Alabama public school districts, excluding those serving special populations, e.g., incarcerated youth, students gifted and talented in math or science, or students who are deaf and/or blind. Alabama recently recognized a new school district, the Saraland City Public Schools; because test data were not available on this district, it was not included in the study.

All data for the study other than the school locale classification were taken from the latest data available on the Alabama Department of Education website.

Demographic data on the districts were from the 20082009 school year. Financial data on the districts were from the 2007-2008 school year. All student achievement data were for the 2006-2007 school year. These included scores on the reading and mathematics portions of the Alabama Reading and Math Test for grades 3, 5, and 8, as well as their $11^{\text {th }}$ grade students' scores on the reading and mathematics portions of the Alabama High School Graduation Exam.
The school locale data were taken from the National Center for Education Statistics (2009) Common Core of Data database. Using the database and definitions from the National Center for Education Statistics' (2009) Common Core of Data, each district was classified as rural, town, suburban, or city. The National Center for Education Statistics (2009) classified Alabama's 130 regular public school districts as follows: 69 rural (53\%), 30 town (23\%), 16 suburban (12\%), and 15 city (12\%). Table 1 disaggregates these data one level further. Alabama ranks high among the states with the largest percentage of rural public schools.

Because the study is a population study, with the district as the unit of analysis, descriptive statistics were used rather than inferential statistics for analyzing the data. This was the correct choice, as population studies do not have the possibility of sampling error, making inferential statistics unnecessary. Effect sizes (Cohen's d) were calculated only between city and rural school districts, as it was between these two categories that the greatest differences were generally found.

\section{Overview of Rural School Districts in Alabama}

Alabama's 90 rural school districts serve a largely poor student population; none have less than $9 \%$ of the students qualifying for free or reduced price lunch, with 78 districts having populations with $90 \%$ or more of the students qualifying for free or reduced price lunch, and at least one district in which every student qualifies. Overall, $60 \%$ of the students in Alabama's public schools qualify for this assistance, up from $54 \%$ a decade earlier. Rural household income in Alabama is only $63 \%$ of the U.S. average, with $19.7 \%$ of Alabama's rural families living in poverty, the fifth highest percentage in the nation. Partially, this is because 34 of Alabama's rural counties have double-digit unemployment and less than $10 \%$ of Alabama's rural population over the age of 25 has finished college (Carter, Lee, \& Sweatt, 2009).

Alabama's 69 rural school districts serve approximately 319,332 students (2008-2009 data), ranking Alabama $11^{\text {th }}$ in the nation for rural student population. Rural school expenditures per pupil in 20072008 were only $\$ 8,211$, among the lowest in the nation. Alabama's rural schools' scores on the 2007-2008 National Assessment of Educational Progress (NAEP) were the eighth lowest in the nation at the fourth grade level and fourth lowest in the nation at the eighth grade level. Their high school graduation rate was only $62.4 \%$, ranking the state the sixth lowest in the nation (Johnson \& Strange, 2009). 
Table 1

Number and Percentages of Alabama School Districts in Each Locale Category

\begin{tabular}{|c|c|c|}
\hline Locale Category & Number of Districts & $\%$ of Total \\
\hline Large City & 0 & $0 \%$ \\
\hline Mid-sized City & 4 & $3 \%$ \\
\hline Small City & 11 & $8 \%$ \\
\hline Total City & 15 & $12 \%$ \\
\hline Large Suburb & 9 & $7 \%$ \\
\hline Mid-sized Suburb & 2 & $2 \%$ \\
\hline Small Suburb & 5 & $4 \%$ \\
\hline Total Suburb & 16 & $12 \%$ \\
\hline Fringe Town & 11 & $8 \%$ \\
\hline Distant Town & 16 & $12 \%$ \\
\hline Remote Town & 3 & $2 \%$ \\
\hline Total Town & 30 & $23 \%$ \\
\hline Fringe Rural & 18 & $14 \%$ \\
\hline Distant Rural & 32 & $25 \%$ \\
\hline Remote Rural & 19 & $15 \%$ \\
\hline Total Rural & 69 & $53 \%$ \\
\hline Total & 130 & $100 \%$ \\
\hline
\end{tabular}

Student populations in rural districts $(\mathrm{M}=4,628$ students) were considerably smaller (Cohen's $d=-.81$ ) than city districts $(\mathrm{M}=14,124$ students $)$ and suburban districts ( $M=7,245$ students), but were larger than town districts ( $M=2,922$ students). National data show that rural districts serve lower percentages of minority students than do districts in city, suburban, or town districts. This is also true in Alabama, where rural districts serve the lowest percentage of minority students (38\%), as compared to town districts (43\%), suburban districts $(50 \%)$, and city districts $(58 \%)$.

\section{Findings}

The results of this study are organized with reference to the research questions.

\section{Rural Student Achievement}

What are the levels of student academic achievement in Alabama's rural schools, as measured by projected four-year dropout rates, percentages of students in career and technical programs, and scores on selected standardized examinations in Alabama's rural public school districts and how do these achievement levels compare to those of students in Alabama's town, suburban, and city public school districts? All district categories presented similar projected four-year dropout rates (Range $=8 \%$ to $10 \%$ ). Rural districts served somewhat larger mean percentages of students in career and technical education programs $(\mathrm{M}=61.73 \%)$ than did districts in any of the other locales (Range $=49.37 \%$ to $58.75 \%$ ). The effect size for the differences between rural and city districts in the percentages of students enrolled in these programs was moderate (Cohen's $\mathrm{d}=$ -.49). Table 2 presents student performance data on Alabama's standardized third grade reading and math tests (2006-2007). Very little difference in test scores was observed across the four locale classifications on either test. Table 3 presents corresponding data on the fifth grade tests. Again, very few differences were found across the four locale classifications. Table 4 presents the data from the eighth grade reading and math tests. At this grade level, there is greater separation among the district locale classifications. Students in the rural districts lagged behind their suburban, city, and town counterparts, respectively. Effect sizes of these differences at this grade level generally ranged from medium to large. 
Table 2

Alabama Test Data (2006-2007) for Grade 3 by District Locale

\begin{tabular}{|c|c|c|c|c|c|}
\hline \multirow{2}{*}{$\begin{array}{l}\text { Reading Test } \\
\text { Grade } 3\end{array}$} & \multicolumn{4}{|c|}{ Mean $\%$ of Students ( Standard Deviation) } & \multirow{2}{*}{$\begin{array}{l}\text { Effect Size (d) } \\
\text { Rural v City }\end{array}$} \\
\hline & City & Suburban & Town & Rural & \\
\hline Level I & $1.03(.62)$ & $1.23(1.36)$ & $1.14(1.18)$ & $.85(.76)$ & -.26 \\
\hline Level II & $15.31(5.79)$ & $14.76(10.81)$ & $14.92(6.79)$ & $14.56(5.88)$ & -.13 \\
\hline Level III & $37.83(5.93)$ & $33.33(11.79)$ & $38.93(7.42)$ & $39.01(7.23)$ & .18 \\
\hline Level IV & $46.78(11.92)$ & $50.68(21.28)$ & $45.00(12.48)$ & $45.71(12.04)$ & -.09 \\
\hline \multicolumn{6}{|l|}{$\begin{array}{l}\text { Math Test } \\
\text { Grade } 3\end{array}$} \\
\hline Level I & $6.99(3.19)$ & $7.98(6.96)$ & $6.61(4.76)$ & $6.16(3.19)$ & -.26 \\
\hline Level II & $16.84(5.17)$ & $17.68(12.83)$ & $18.7(17.67)$ & $16.6(46.87)$ & -.03 \\
\hline Level III & $28.36(2.78)$ & $25.70(7.58)$ & $28.55(6.17)$ & 29.51(5.62) & .26 \\
\hline Level IV & $47.81(9.99)$ & $48.64(21.90)$ & $46.13(14.60)$ & $47.69 \quad(13.85)$ & -.01 \\
\hline
\end{tabular}

Note: Level I = Does not meet standard; Level II = Partially meets standard; Level III = Meets standard; Level IV = Exceeds standard.

Table 3

Alabama Test Data (2006-2007) for Grade 5, by District Locale

\begin{tabular}{|c|c|c|c|c|c|}
\hline \multirow{2}{*}{$\begin{array}{l}\text { Reading Test } \\
\text { Grade } 5\end{array}$} & \multicolumn{4}{|c|}{ Mean \% of Students ( Standard Deviation) } & \multirow{2}{*}{$\begin{array}{l}\text { Effect Size (d) } \\
\text { Rural v City }\end{array}$} \\
\hline & City & Suburban & Town & Rural & \\
\hline Level I & $1.21(.77)$ & $1.38(.97)$ & $1.34(.93)$ & $1.57(1.27)$ & .34 \\
\hline Level II & $16.66(6.16)$ & $13.68(6.09)$ & $17.42(7.12)$ & $15.91(6.51)$ & -.12 \\
\hline Level III & $35.38(7.48)$ & $32.38(6.40)$ & $34.50(6.02)$ & $33.72(5.41)$ & -.25 \\
\hline Level IV & 46.75 (13.09) & $52.56(12.26)$ & $46.74(12.32)$ & $48.80(11.18)$ & .17 \\
\hline \multicolumn{6}{|l|}{$\begin{array}{l}\text { Math Test } \\
\text { Grade } 5\end{array}$} \\
\hline Level I & $.76(.54)$ & $.91(.97)$ & $1.07(.80)$ & $1.18(1.17)$ & .46 \\
\hline Level II & $24.95(1.20)$ & $21.39(9.52)$ & $25.01(9.96)$ & $23.69(9.51)$ & -.19 \\
\hline Level III & $36.51(5.8)$ & $37.26(5.55)$ & $37.73(5.55)$ & $37.71(5.16)$ & .22 \\
\hline Level IV & $37.77(14.44)$ & $40.44(13.13)$ & 36.19 (13.08) & $37.41(13.08)$ & -.03 \\
\hline
\end{tabular}

Note: Level I = Does not meet standard; Level II = Partially meets standard; Level III = Meets standard; Level IV = Exceeds standard. 
Table 4

Alabama Test Data (2006-2007) for Grade 8, by District Locale

\begin{tabular}{|c|c|c|c|c|c|}
\hline \multirow{2}{*}{$\begin{array}{l}\text { Reading Test } \\
\text { Grade } 8\end{array}$} & \multicolumn{4}{|c|}{ Mean $\%$ of Students ( Standard Deviation) } & \multirow{2}{*}{$\begin{array}{l}\text { Effect Size (d) } \\
\text { Rural v City }\end{array}$} \\
\hline & City & Suburban & Town & Rural & \\
\hline Level I & $1.19(.69)$ & $.85(.79)$ & $1.63(1.89)$ & $1.64(1.09)$ & .49 \\
\hline Level II & $27.10(9.89)$ & $24.25(12.79)$ & $27.65(11.04)$ & $30.37(9.42)$ & .34 \\
\hline Level III & 37.14 (4.49) & $36.51(8.86)$ & $37.53(4.66)$ & $40.46(3.79)$ & .80 \\
\hline Level IV & $34.57(13.75)$ & 38.39 (21.10) & $33.19(12.81)$ & $27.53(10.26)$ & -.58 \\
\hline \multicolumn{6}{|l|}{$\begin{array}{l}\text { Math Test } \\
\text { Grade } 8\end{array}$} \\
\hline Level I & $.01(.02)$ & $.00(.00)$ & $.00(.00)$ & $.00(.02)$ & -.50 \\
\hline Level II & $33.70(15.73)$ & $28.40(15.81)$ & 36.13 (16.97) & $37.46(12.37)$ & .27 \\
\hline Level III & $41.64(6.37)$ & $44.06(9.36)$ & $43.48(7.62)$ & $47.21(6.26)$ & .88 \\
\hline Level IV & $24.66(13.12)$ & $27.54(21.26)$ & $20.40(11.52)$ & $15.33(8.19)$ & -.85 \\
\hline
\end{tabular}

Note: Level I = Does not meet standard; Level II = Partially meets standard; Level III = Meets standard; Level IV = Exceeds standard

Table 5 presents the results of eleventh-grade student performance on the reading and math portions of the Alabama High School Graduation Examination (2006-2007). Eleventh grade was chosen because it is at this grade level that Alabama expects all students to be able to pass this examination. Although there was little difference in scores across locale classification categories for student scores in math, large differences (Cohen's $d=-1.73$ ) were found in the percentages of students passing the reading exam and in the percentages of students passing the reading exam with an advanced score. Students in rural districts lagged well behind all other classifications in reading.

\section{Table 5}

Alabama Test Data (2006-2007) for Grade 11 by District Locale

\begin{tabular}{llcccc}
\hline Reading G 11 & \multicolumn{3}{c}{ Mean \% of Students ( Standard Deviation) } & \multirow{2}{*}{$\begin{array}{l}\text { Effect Size (d) } \\
\text { Rural v City }\end{array}$} \\
\cline { 2 - 5 } \%Passing & City & Suburban & Town & Rural & \\
\cline { 2 - 5 } & $93.72(10.25)$ & $93.00(10.69)$ & $92.48(12.87)$ & $73.84(12.57)$ & -1.73 \\
$\begin{array}{l}\text { \%Passing } \\
\text { Advanced }\end{array}$ & $59.22(18.69)$ & $57.34(22.38)$ & $54.50(22.31)$ & $23.38(22.49)$ & -1.73 \\
$\begin{array}{l}\text { Math G 11 } \\
\text { \%Passing }\end{array}$ & $67.95(7.06)$ & $64.65(12.82)$ & $65.13(9.08)$ & $67.48(7.52)$ & -.06 \\
$\begin{array}{l}\text { \%Passing } \\
\text { Advanced }\end{array}$ & $19.75(10.07)$ & $21.08(18.63)$ & $20.50(13.23)$ & $18.29(10.31)$ & -.14 \\
\hline
\end{tabular}




\section{Socio-economic Level of the Students}

To what extent does the socio-economic level of the students the districts serve vary by the locale of the district? As is illustrated in Table 6, rural districts $(\mathrm{M}=$

Table 6

Range and Mean \% of Students Qualifying for Free and Reduced Lunch per Locale Classification
$60 \%$ ) served only slightly higher (Cohen's $d=.26$ ) percentages of students qualifying for free or reduced price lunch than did city districts $(\mathrm{M}=55 \%)$, suburban districts $(M=50 \%)$, and town districts $(M=57 \%)$.

District Classification

\begin{tabular}{|c|c|c|c|c|c|}
\hline & $\begin{array}{l}\text { City } \\
(n=15)\end{array}$ & $\begin{array}{l}\text { Suburban } \\
(\mathrm{n}=16)\end{array}$ & $\begin{array}{l}\text { Town } \\
(\mathrm{n}=31)\end{array}$ & $\begin{array}{l}\begin{array}{l}\text { Rural } \\
(\mathrm{n}=69)\end{array} \\
\end{array}$ & \\
\hline & \multicolumn{4}{|c|}{$\%$ Free and Reduced Lunch } & $\begin{array}{l}\text { Effect size (d) } \\
\text { Rural v City }\end{array}$ \\
\hline Range & $17-87$ & $0-90$ & $25-100$ & $9-100$ & .26 \\
\hline Mean (SD) & $55(20)$ & $50(3)$ & $57(2)$ & $60(18)$ & \\
\hline
\end{tabular}

\section{Per Pupil Expenditures}

To what extent do per-pupil expenditures vary in relation to the locale of the school district? Table 7 presents descriptive data on financial variables across the four categories of district locale. Total expenditures per pupil for rural districts $(\mathrm{M}=\$ 8,211)$ are less than for city $(M=\$ 8,973)$ and suburban districts $(M=8,741)$, but slightly higher than for town districts $(M=\$ 8,176)$. However, the effect size of the differences in total expenditures per pupil between rural and city districts was small (Cohen's $\mathrm{d}=-.09$ ).

Table 7

Range, Means, and Standard Deviations of District per Pupil Expenditures

District Classification

\begin{tabular}{llllll} 
& $\begin{array}{l}\text { City } \\
(\mathrm{n}=15)\end{array}$ & $\begin{array}{l}\text { Suburban } \\
(\mathrm{n}=16)\end{array}$ & $\begin{array}{l}\text { Town } \\
(\mathrm{n}=31)\end{array}$ & $\begin{array}{l}\text { Rural } \\
(\mathrm{n}=69)\end{array}$ & $\begin{array}{l}\text { Effect size (d) } \\
\text { Rural v City }\end{array}$ \\
\hline & \multicolumn{5}{c}{ Total Per Pupil Expenditures, in Dollars (SD) } \\
\hline Range & $7,892-10,956$ & $7,305-11,514$ & $7,142-9,685$ & $7,027-11,798$ & -.09 \\
Mean (SD) & $8,973(784)$ & $8,741(1,282)$ & $8,176(545)$ & $8,211(796)$ & \\
\hline
\end{tabular}

\section{District Funding Allocations}

To what extent do the percentages of funds districts spend on instruction, on administration, and on transportation vary by the locale of the school district? As is illustrated in Table 8, rural schools spent approximately the same (Cohen's $d=0.18$ ) percentage of their budgets on instruction as did school districts in other locales (Mean Range $=62 \%$ to $67 \%$ ).
However, although the mean for rural instructional budgets was similar to other locales, a wide variation in expenditure in this area occurred among rural schools (31\%-77\%). All locale classifications spent between 4 and 5 percent of their budgets on administration $($ Cohen's $d=0)$. However, rural districts spent considerably more (Cohen's $\mathrm{d}=1.18$ ) on transportation $(\mathrm{M}=7 \%)$ than did city districts $(\mathrm{M}=4 \%)$, suburban districts $(M=3 \%)$, and town districts $(M=4 \%)$. 
Table 8

Range, Means, and Standard Deviations on District Expenditure Patterns

\begin{tabular}{|c|c|c|c|c|c|}
\hline & \multirow[b]{2}{*}{$\begin{array}{l}\text { City } \\
(n=15)\end{array}$} & \multicolumn{2}{|c|}{ District Classification } & \multirow[b]{2}{*}{$\begin{array}{l}\text { Rural } \\
(n=69)\end{array}$} & \multirow{2}{*}{$\begin{array}{l}\text { Effect size (d) } \\
\text { Rural v City }\end{array}$} \\
\hline & & $\begin{array}{l}\text { Suburban } \\
(\mathrm{n}=16)\end{array}$ & $\begin{array}{l}\text { Town } \\
(n=31)\end{array}$ & & \\
\hline \multicolumn{6}{|c|}{$\%$ of Expenditures for Instructional Services } \\
\hline Range & $58-72$ & $42-74$ & $57-74$ & $31-77$ & 0.18 \\
\hline Mean (SD) & $65(4)$ & $62(8)$ & $67(5)$ & $64(7)$ & \\
\hline \multicolumn{6}{|c|}{$\%$ of Expenditures for Administration } \\
\hline Range & $2-6$ & $1-7$ & $3-6$ & $2-6$ & 0 \\
\hline Mean (SD) & $4(1)$ & $4(2)$ & $5(1)$ & $4(1)$ & \\
\hline \multicolumn{6}{|c|}{$\%$ of Expenditures for Transportation } \\
\hline Range & $1-7$ & $0.3-6$ & $0-10$ & $1-15$ & 1.18 \\
\hline Mean (SD) & $4(2)$ & $3(2)$ & $4(2)$ & $7(3)$ & \\
\hline
\end{tabular}

\section{Revenue Sources}

To what extent do revenue sources vary by the locale of the district? As is illustrated in Table 9, rural districts derived a significantly higher percentage $(\mathrm{d}=$ 1.08) of their revenues from the State $(M=61 \%)$ than did city districts $(M=50 \%)$. Suburban districts on average derived a considerably lower percentage of their revenues from the State $(\mathrm{M}=41 \%)$ than did the other districts, whereas town districts fell between rural and city districts on this statistic $(\mathrm{M}=56 \%)$. However in all four locales, much variation in the level of State funding occurred among districts. This is likely due to the fact that Alabama's educational finance program is a foundation program, with the State providing funds to poorer districts to offset their local funding disadvantage with more wealthy districts. In Alabama, rural districts are more likely to be less advantaged than urban or suburban districts.

\section{Table 9}

Range, Means, and Standard Deviations on District Revenues

District Classification

\begin{tabular}{lllll}
$\begin{array}{l}\text { City } \\
(\mathrm{n}=15)\end{array}$ & $\begin{array}{l}\text { Suburban } \\
(\mathrm{n}=16)\end{array}$ & $\begin{array}{l}\text { Town } \\
(\mathrm{n}=31)\end{array}$ & $\begin{array}{l}\text { Rural } \\
(\mathrm{n}=69)\end{array}$ & $\begin{array}{l}\text { Effect Size (d) } \\
\text { Rural v City }\end{array}$ \\
\hline \% of Revenues from State Funding \\
\hline $50(12)$ & $18-68$ & $28-67$ & $30-72$ & 1.08 \\
& $41(18)$ & $56(11)$ & $61(8)$
\end{tabular}

Local Mill Levy

$\begin{array}{llllll}\text { Range } & 15-111 & 23-63 & 15-74 & 11-210 & .50 \\ \text { Mean (SD) } & 41(23) & 44(10) & 39(15) & 29(25)\end{array}$




\section{Discussion}

In the area of test performance, students in Alabama's rural schools fall behind their peers in town, suburban, or city districts on standardized examinations. This finding matched Lee and McIntire's (2000) conclusion that rural students' performance on standardized tests is significantly poorer than non-rural students in some states, but did not match the findings of the National Center for Education Statistics (2003) or of the Rural School and Community Trust (2009) which indicated that rural students generally performed as well as their counterparts in non-rural schools. In terms of projected four-year dropout rates, Alabama's rural schools were very comparable with schools in all other locales and were one percentage point higher than suburban districts. Provasnik et al. (2007) also found relatively comparable dropout rates among the four locale classifications, but, in this case, rural schools had a slightly higher dropout rate than their suburban counterparts.

There was relatively little difference among the socio-economic levels of the families served in Alabama's rural districts, town districts, and city districts, but $10 \%$ more rural students qualified for free or reduced price lunch than did suburban students. This differed from the findings of Provasnik et al. (2007), who found that the percentage of rural students qualifying for lunch assistance was $20 \%$ lower than for cities and $15 \%$ lower than for towns. It also differed from Johnson and Strange's (2007) study, which indicated that rural schools tend to serve poorer student populations than all other locale categories.

\section{Patterns of Expenditure}

Alabama's rural school districts spent a considerably higher percentage of their budgets on transportation than did districts in any other locale classification. This matched Reeves' (2003) and Wolfson and Carskadon's (2003) findings that rural school districts transport their students over much greater distances than districts in other locales.

Alabama's rural schools spent similar percentages of their budgets on both administration and instruction as did districts in other locales, matching Odden and Picus' (2004) findings. Although, on average, rural districts spent over $\$ 900$ less per pupil in overall expenditures than did their urban counterparts, the high variation in per pupil expenditures among the districts in each locale category resulted in a very low effect size for this difference.

\section{Sources of Revenue}

Alabama's rural districts derive significantly higher percentages of their budgets from State revenues than do districts in town, suburban, or city locales. There is a $20 \%$ difference between rural and suburban schools on this factor. In part, this is because Alabama's rural districts also levied considerably lower mill levies than did their counterparts in other locales and relied upon the State for a considerably higher percentage of their budgets. This confirmed Alexander and Salmon's (1995) concern that without higher local mill levies, overall per pupil expenditures suffer.

\section{Conclusions}

Other than in math performance on the $11^{\text {th }}$ grade Alabama High School Graduation Examination, where rural students' performance was essentially the same as that of their peers in other locale categories, students in rural schools performed below their peers in both reading and math, with the gap widening at the upper grade levels. Unfortunately, the results of this study do not provide clear insight into why this occurs.

Typically, district test score results have a strong, negative relationship to the percentage of students qualifying for free or reduced price lunch. In this case, there was little difference in socio-economic background of the students in rural districts compared to those in non-rural districts.

Many studies have found negative relationships between the percentage of minority students in a district and performance on standardized tests. This study revealed that Alabama's rural districts serve a lower percentage of minority students than do its non-rural districts, yet the rural districts' test scores lag behind. Traditional wisdom, yet mixed research results, suggest a positive relationship between expenditures per pupil and student performance; however, there is little, if any, difference in the expenditures per pupil of rural districts and those of non-rural districts. Research on the issue is not definitive, but some research (e.g., Jacques \& Wade, 2002) has shown that the percentage of the budget spent on instructional services corresponds positively with student performance; however, rural districts in Alabama spend approximately the same percentages of their budgets on instruction and administration as their nonrural counterparts. They do, however, spend a higher percentage of their budgets on transportation.

Rural districts in Alabama are somewhat smaller than non-rural districts, but the research on this factor is 
inconclusive and gives little insight into how and why district size would affect student performance. Because this study used the district as the unit of analysis, it did not investigate the relationship between student performance and school size; however, the dynamics of this factor are also not clearly explained by existing research.

Perhaps some insight into the results can be found in the variations (ranges and standard deviations) of the independent variables among the districts in each locale category. These variations are so great for the percentages of students who qualify for free or reduced price lunch, per pupil expenditures, percentages of the overall budgets spent on administration and instruction, and revenue sources that there is clearly substantial variation among the districts within each category, perhaps overshadowing the variations among the locale categories. In other words, rural schools (and schools in the other locale categories) cannot be considered to be homogeneous in regard to these variables.

Consequently, attempts to improve the performance of rural schools cannot be addressed through policy or programmatic changes aimed at rural schools as a category; each district, or perhaps even each school, must be considered individually.

Clearly, there are special challenges faced by rural school districts, such as the extensive transportation they

\section{References}

Alabama State Department of Education. (2009). Public data reports. Montgomery, AL: Author. Retrieved January 19, 2011 from http://www.alsde.edu

Alexander, K., \& Salmon, R. G. (1995). Public school finance. Boston: Allyn \& Bacon.

Allington, R. L., \& Johnston, P. (1989). Coordination, collaboration, and consistency: The redesign of compensatory and special education interventions. In R. E. Slavin, N. L. Karweit, \& Nancy A. Madden (Eds.), Effective programs for students at risk (pp. 320-354). Needham Heights, MA: Allyn \& Bacon.

Arnold, M. (2004). Guiding rural schools and districts: A research agenda. Aurora, CO: Mid-continent Research for Education and Learning.

Bickel, R., \& Howley, C. (2000). The influence of scale on school performance: A multi-level extension of the Matthew Principle. Education Policy Analysis Archives, 8(22). Retrieved from http://epaa.asu.edu/ojs/article/view/413

Carter, G., Lee, L., \& Sweatt, O. (2009). Lessons learned from rural schools. Montgomery, AL: Alabama Department of Agriculture and Industrial Center for Rural Alabama.

Driscoll, L. E. (2008). The effectiveness, value, and importance of small school districts. Lexington, must offer and their inability or unwillingness to raise more funds through local mill levies; additional research is needed on the effects of these two variables. Further research is needed on the key variables that affect student performance, e.g., the quality of the teaching and leadership corps available in rural areas. Further research is also needed on the extent to which rural schools and the communities they serve may represent a different culture than non-rural schools, a culture which affects student performance. In decades past, graduates, or even dropouts, from rural schools could find work in the agricultural and timber sectors of their communities that relied more on a strong back than a solid education. This may have diminished the importance of education in many rural communities. Today, with the rise of mechanization and the decline of the cotton industry in Alabama, such employment opportunities are vastly reduced. Have today's rural communities fully accepted the crucial importance of strong education? Research is required in this area.

The variation among the performance results of rural school districts suggests that some districts have found at least partial solutions to these challenges. Further research is needed on these successful solutions and their applicability to other rural schools.

MA: Massachusetts Association of School Superintendents.

Farmer, T. W., Leung. M-C., Banks, J. B., Schaefer. V., Andrews, B., \& Murray, R. A. (2006). Adequate yearly progress in small rural schools and rural lowincome schools. The Rural Educator, 27(3), 1-14.

Hanushek, E. A. (1997). Assessing the effects of school resources on student performance: An update. Educational Evaluation and Policy Analysis, 19(2), 141-164.

Howley, C. B., (1996). Compounding disadvantage: The effects of school and district size on student achievement in West Virginia. Journal of Research in Rural Education, 12, 25-32.

Howley, C. (2003). School reform proposals: The research evidence, small schools. Retrieved January 19, 2010 from http://www.asu.edu.edu/educ/eps1/EPRU/documents/ E PRO 2002-101/Chapter 03-Howley-Final.pdf

Howley, A., \& Maynard, S. (2009). Parent and community involvement in rural schools. Washington, DC: Educational Resource Information Center. Retrieved from http://tinyurl.com/ruraledu

Howley, C., Strange, M., \& Bickel, R. (2000). Research about school size and school performance in 
impoverished communities. (ERIC Document Reproduction Service No. ED EDO-RC-00-10)

Huang, G., \& Howley, C. (1993). Mitigating disadvantage: Effects of small-scale schooling on student achievement in Alaska. Journal of Research in Rural Education, 9(3), 137-149.

Jacques, C., \& Wade, B. B. (2002). Relationship between types of school district expenditures and student performance. Applied Economic Letters, 15, 9971002.

Johnson, J. (2006). More doesn't mean better. Randolph, VT: The Rural School and Community Trust Policy Program.

Johnson, J., \& Strange, M. (2007). Why rural matters 2007: The realities of rural education growth. Arlington, VA: The Rural School and Community Trust.

Johnson, J., \& Strange, M. (2009). Why rural matters 2007: State and regional challenges and opportunities. Arlington, VA: The Rural School and Community Trust. Retrieved from http://www.ruraledu.org/articles.php?id=2312

Johnson, J., Strange, M., \& Madden, K. (2010). The rural dropout problem: An invisible achievement gap. Retrieved January 19, 2011 from http://ww.ruraledu.org/print_article.php?id=2474

Lee, J., \& McIntire, W. G. (2000). Interstate variation in mathematics achievement of rural and non-rural students. Journal of Research in Rural Education, 16(3), 168-181.

Lee, V. E., \& Smith, J. B. (1997). High school size; Which works best and for whom? Educational Evaluation and Policy Analysis, 19(3), 205-227.

Leithwood, K., \& Jantzi, D. (2009). A review of empirical evidence about school size effects: A policy perspective. Review of Educational Research, 79(1), 464-490.

Lomotey, K., \& Swanson, A. D. (1989). Urban and rural schools research: Implications for school governance. Education and Urban Society, 21(4), 436-454.

National Center for Education Statistics. (1997). Statistical analysis report: Characteristics of small and rural school districts. Washington, DC: Author. Retrieved, from http://nces.ed.gov/pubs97/web/97529.asp

National Center for Education Statistics. (2003). National Assessment of Educational Progress, the nation's report card. Washington, DC: Author.

National Center for Education Statistics. (2007). Status of education in rural America. Washington, DC: Author.
National Center for Education Statistics. (2009). Status of education in rural America. Washington, DC: Author. Retrieved from http://nces.ed.gov/pubs2007/ruraled/

Niskanen, W. A. (1988). Student performance and school district size. In W. Niskanen (Ed.), Policy analysis and public choice (pp. 124-134). Northampton, MA: Edward Elgar.

Odden, A. (Ed.). (1991). Education policy implementation. Albany, NY: State University of New York Press.

Odden, A. R., \& Picus, L. O. (2004). School finance: A policy perspective ( ${ }^{\text {rd }}$ ed.). Boston: McGraw Hill.

Paik. S., \& Phillips, R. (2002). Student mobility in rural communities: What are the implications for student achievement? Naperville, IL: North Central Regional Educational Laboratory.

Provasnik, S., KewalRamani, A., Coleman, M.M., Gilbertson, L., Herring, W., \& Xie, Q. (2007). Status of education in rural America. Washington, DC: National Center for Education Statistics.

Reynolds, A. J., \& Wolfe, B. (1999). Special education and school achievement: An exploratory analysis with a central-city sample. Educational Evaluation and Policy Analysis, 21(3), 249-269.

Reeves, C. (2003). Implementing the No Child Left Behind Act: Implications for rural schools and districts. Naperville, IL: North Central Regional Educational Laboratory.

Rural Education. (2004, September 21). Education Week. Retrieved January 19, 2011 from http://www.edweek.org/re/issues/ruraleducation/?print $=1$

Swanson, C. B. (2003). Who graduates? Who doesn't?: A statistical portrait of public high school graduation, class of 2001. Washington, DC: The Urban Policy Institute. Retrieved January 19, 2011 from http://tinyurl.com/urban-org

The Rural School and Community Trust. (2009). Percentage of rural school districts with reading performance above state median, per NCLB. Rural Policy Matters. Arlington, VA: Author.

Werblow, J., \& Duesbery, L. (2009). The impact of high school size on math achievement and dropout rate. Chapel Hill, NC: The University of North Carolina Press.

Wolfson, A. R., \& Carskadon, M. A. (2003). Understanding adolescents' sleep patterns and school performance: A critical appraisal. Sleep Medicine Reviews, 7(6), 491-506.

Dr. Lindahl is a professor at Alabama State University. He has served as a teacher and administrator in K-12 education and on the educational leadership faculty at several universities. He has worked in the United States, Canada, England, Spain, Brazil, and Mexico. 